\title{
Extracts from medicinal plants inhibit cancer cell proliferation, induce apoptosis in ovary, lung and neuronal cancer cell lines
}

\author{
Wafa Ghali ${ }^{1 *}$, David Vaudry ${ }^{2}$, Thierry Jouenne ${ }^{3}$, Mohamed Nejib Marzouki ${ }^{1}$ \\ From Metabolism, Diet and Disease 2014: Cancer and metabolism \\ Washington DC, USA. 28-30 May 2014
}

\section{Background}

For thousands of years natural products, especially plants and vegetables, have been used to fight against various diseases such as cancer, microbial infections and even neurodegenerative diseases. It has been shown that consumption of plants and vegetables have a direct influence on the proliferation, angiogenesis, metastasis of cancer cells.

\section{Materials and methods}

Our work aimed to evaluate the antioxidant activity, protective properties and anti-proliferative capacity of Lycium europeaum and Jatropha podagrica extracts on the proliferation and evolution of A547 (ovarian cancer cell line), OVCAR-3 (human ovary adenocarcinoma cell line), A549 (Human lung adenocarcinoma cell line) and PC12 (rat adrenal medulla Pheochromocytoma cells). The cytotoxicity of the studied extracts was also evaluated on cerebellar granule cells. Cell viability was monitored using thiazolyl blue tetrazolium bromide (MTT) reduction assay. Induction of apoptosis in treated cells was measured through caspases 3/7 activity. Cytoprotective properties of the extracts were assessed by monitoring the effect of induced-oxidative stress damages on cellular macromolecules. Free radical scavenging capacity was investigated by different methods such as DPPH and reducing power.

\section{Results}

Extracts were found to contain components that inhibit cell proliferation and display cytotoxic activity on cancer cells but not on normal cells. The cytotoxicity of the studied

\footnotetext{
'Laboratory of Protein Engineering and Active Biomolecules, National Institute of Applied Sciences and Technology, University of Carthage, Centre Uurbain Nord, Tunis, Tunisia

Full list of author information is available at the end of the article
}

extracts was also evaluated on young cerebellar granule cells and found to be non-significant. The anti-proliferative activity appeared to be mediated by apoptotic mechanisms, as suggested by activation of caspases $3 / 7$ following cell exposure to the extracts. Lycium, as well as Jatropha extracts, seemed to be able to initiate cellular pathways that led to apoptosis when added to tumoral cells but did not show a significant cytotoxicity in contact with normal cells. Results also showed that the extracts protected lipids, proteins and DNA against oxidative stress damages induced by $\mathrm{H} 2 \mathrm{O} 2$ via scavenging $\mathrm{ROS}$. The antioxidant capacity of the studied plant extracts was correlated with the antiproliferative activity.

\section{Conclusion}

The present data demonstrate that Lycium europaeum and Jatropha podagrica may inhibit the proliferation of cancer cells and induce apoptosis and could provide protection from oxidative stress diseases thanks to their high antioxidant molecules content.

\section{Acknowledgements}

This work was supported by the Tunisian Ministry of High Education and Scientific Research, INSERM and Rouen University. We thank all the team of the U INSERM 982 "Différenciation \& Communication Neuronale \&

Neuroendocrine" laboratory and the team at the PISSARO proteomic facility (IRIB) for all their help.

\section{Authors' details}

'Laboratory of Protein Engineering and Active Biomolecules, National Institute of Applied Sciences and Technology, University of Carthage, Centre Uurbain Nord, Tunis, Tunisia. ${ }^{2}$ INSERM U982, Différenciation \&

Communication Neuronale \& Neuroendocrine, Laboratory, URouen, IRIB, Mont-Saint-Aignan, France. ${ }^{3}$ CNRS UMR 6270, Polymères, Biopolymères, Surfaces Laboratory, PISSARO proteomic facility, URouen, Mont-Saint-Aignan, France. 
Submit your next manuscript to BioMed Central and take full advantage of:

- Convenient online submission

- Thorough peer review

- No space constraints or color figure charges

- Immediate publication on acceptance

- Inclusion in PubMed, CAS, Scopus and Google Scholar

- Research which is freely available for redistribution 